\title{
Radiation-induced bystander effects: Relevance for radiation protection of human and non-human biota
}

\author{
C. MOTHERSILL ${ }^{1}$, C. SEYMOUR ${ }^{1}$
}

(Manuscript received 18 November 2004, accepted le 11 April 2005)

ABSTRACT In this paper our current knowledge of the mechanisms underlying the induction of bystander effects by low dose low LET ionizing radiation is reviewed in the context of relevance to radiation protection issues. The question of how bystander effects may be related to observed adaptive responses, systemic genomic instability or other effects of low doses exposures is also considered. Bystander effects appear to be the result of a generalized stress response in tissues or cells. The signals may be produced by all exposed cells, but the response may require additional system parameters to exist in order to be expressed. The major response involving low LET radiation exposure discussed in the existing literature is a death response. This can manifest as apoptotic cell death, terminal differentiation, reproductive cell death or necrosis. While a death response might appear to be adverse, the position is argued in this paper, that it can in fact be protective and remove damaged cells from the reproducing population. Since many cell populations carry damaged cells without being exposed to radiation (so-called "background damage"), it is possible that low dose radiation exposures cause removal of cells damaged by agents other than the test dose of radiation. This mechanism would lead to the production of " $u$ - or $n$ shaped" dose response curves. In this scenario, the level of harmful or beneficial response will be related to the background damage carried by the cell population and the genetic program determining response to damage. This model may be particularly important when attempting to predict the consequences of mixed exposures involving radiation and other environmental stressors on biota.

Key words: bystander effect / low dose / apoptotic cell death / genomic toxicity / genomic instability

RÉSUMÉ Effet bystander : conséquences potentielles en radioprotection.

Cette publication a pour objectif de mettre en évidence la connaissance actuelle des mécanismes de l'effet bystander (abscopal) à faible dose de rayonnements ionisants et les conséquences potentielles en radioprotection. La relation de l'effet bystander à la réponse adaptative (hormésis), à l'instabilité génomique et à d'autres effets à faible dose sera abordée. L'effet bystander apparaît être le résultat d'une réponse généralisée tissulaire ou cellulaire. Le signal peut être produit par toutes les cellules exposées mais la réponse requiert des paramètres cellulaires spécifiques pour être exprimé. La principale réponse suivant une exposition à faible débit de dose de RI est la mort cellulaire. Elle peut être d'origine apoptotique, une différentiation terminale, une mort mitotique ou une nécrose. Alors que la mort cellulaire peut apparaître comme un effet adverse, les auteurs prennent le parti que cet effet est en fait un effet protecteur et permettent d'éliminer les cellules endommagées des

\footnotetext{
${ }^{1}$ Medical Physics and Applied Radiation Sciences Unit, McMaster University, Hamilton, Ontario, Canada L8S 4K1.
} 


\begin{abstract}
cellules en division. Depuis que l'on a mis en évidence que des cellules porteuses de dommages sans avoir été irradiées (appelé aussi « dommage de bruit de fond »), il est possible d'imaginer que les expositions à faibles doses d'irradiation peuvent également être à l'origine de l'élimination des cellules porteuses de mutation du à d'autre agents génotoxiques que les rayonnements ionisants. Ce mécanisme pourrait mener à des formes de courbe dose réponse très différentes. Dans ce scénario, le niveau de réponse bénéfique ou nuisible serait lié au niveau de dommage des cellules non touchées et le programme génétique détermine la réponse cellulaire au dommage. Cette modélisation serait particulièrement importante pour permettre de prédire les conséquences d'une exposition mixte impliquant rayonnements ionisants et autre stress environnementale.
\end{abstract}

\title{
1. Introduction
}

Radiation-induced bystander signals appear to coordinate cellular responses even in cells not directly exposed or traversed by radiation. This work has led to a paradigm shift in radiobiology over the last 5-10 years (see reviews; Morgan, 2003; Mothersill and Seymour, 2003; Lorimore and Wright, 2003; Little and Morgan, 2003). Prior to this it was held that DNA double strand breaks and cellular survival/damage were inextricably linked and that radiation damage could be defined as a function of DNA double strand breaks. This is now being challenged because of an increasing number of studies demonstrating indirect or non-targeted effects and coordinated tissue responses (Barcellos-Hoff and Brooks, 2001). These appear to saturate at low doses and lead to a breakdown of the dose response relationship which dominates at high doses (Prise et al., 2003; Seymour and Mothersill, 2000). The low dose mechanisms may mitigate or exacerbate the direct effects of the dose and dominate the results at doses below 0.5 Gy (Seymour and Mothersill, 2000; Zhou et al., 2003). Signal production has been detected at doses as low as $5 \mathrm{mGy}$ although at these doses the recipient cell may transduce the signal in a different way (Keyes et al., 2005). Current conventional models of radiation dose response do not accommodate these new findings and as long as the mechanisms remain unclear, modeling low dose effects is difficult and uncertainty is high.

While there is obvious interest in general in this field, the key applications are likely to be in development of new drugs for use in radiation protection and normal tissue damage control. A novel mechanism for coordination of tissue responses is clearly being induced by radiation and probably by other substances. This offers new avenues for development of drugs aimed not at cell destruction but at restoring the tissues own control and coordination of response following DNA damage. 


\section{Bystander effects and induced responses}

Many of the newly recognised effects are similar to systemic stress or innate immune responses, in that there is no simple relationship between exposure and effect and the outcome is not obviously dependent on dose or number of cells hit by radiation (Zhou et al., 2002; Azzam et al., 2003; Geard et al., 2002; Belyakov et al., 2003). Mitochondria and reactive oxygen species appear to be important to the coordination and regulation of these effects (Limoli and Giedzinski, 2003; Mothersill et al., 2000; Iyer and Lehnert, 2002a; Shao et al., 2003). So far, research by our group and others has suggested that radiation causes hit cells to produce signals, which can be received by cells close to or distant from the targeted cell (Gerashchenko and Howell, 2003; Lorimore et al., 2003; Little et al., 2002; Reznikov et al., 2000; Emerit et al., 1997; Faguet et al., 1984). The recipient cells transduce the signals and appear to coordinate an appropriate response. Responses recorded to date include initiation of apoptosis, differentiation or proliferation (Belyakov et al., 2002, 2003; Trosko, 1998; Dent et al., 2003). These coordinated responses can be protective as for example, an apoptotic response can remove an abnormal cell from the population, but the response can also involve fixation of mutations, induction of genomic instability or cellular transformation as premalignant responses. Which response predominates appears to depend on genetic and environmental influences and not to be related to dose (Baverstock, 2000; Mothersill et al., 2001).

\section{The signaling mechanisms}

The nature of the signal(s) is (are) unknown although the properties are becoming clearer. Much of the phenomenological data are suggestive of a very small (less than 1000 Daltons) peptide molecule or biogenic amine but it is also possible to argue for long-lived radicals or nitric oxide leading to peroxide or aldehyde release from cells (Emerit et al., 1997; Davies, 2003; Balcer-Kubiczak et al., 2002; Azzam et al., 2002). Clearly many signals may be involved and the sequence of activation of these can lead to confusing results. The mechanisms by which the cells coordinate their responses are also unknown but signaling which leads to persistently increased ROS, and modulation of biochemical pathways in mitochondria (particularly HMP shunt) have been demonstrated (Mothersill et al., 2000; Lehnert and Iyer, 2002; Iyer and Lehnert, 2002a; Burlakova et al., 2001).

\section{Methods for studying bystander effects}

Many in vitro models to study these effects have been developed. These can involve irradiation using low doses of high or low LET radiation using 
microbeams or low fluences of alpha particles where not all cells in the field are hit by a radiation traversal. Effects are looked for in "un-hit" cells (Osterreicher et al., 2003; Prise et al., 1998, 2002; Sawant et al., 2002; Iyert and Lehnert, 2002b; Nagasawa and Little, 1992). A simple medium transfer protocol which enables low dose, low LET radiation effects, to be studied has also been published by our own group (Mothersill and Seymour, 1997a, 1998). This work has shown that medium from irradiated cells and from the distant progeny of irradiated cells contains a factor or factors which can significantly alter survival of cells which were never irradiated and were never in contact with irradiated cells. Inhibitors of the production of the factor (or response to it), include the MAO inhibitor L-deprenyl and lactate (Mothersill et al., 2000; Seymour et al., 2003). A major feature of current research in the field is aimed at dissecting out the relative importance of signal production and cellular response. Results to date suggest that these are independently modulated and that cell lines not producing a signal may respond to one. This clearly implicates a genetic component in the mechanism which is further indicated by the in vivo work available (Coates et al., 2003; Lorimore et al., 2001).

\section{Bystander effects and genomic instability}

One of the most interesting areas in this field is the link between bystander effects and induction and perpetuation of genomic instability (Morgan, 2003; Mothersill and Seymour, 2003; Lorimore and Wright, 2003; Little and Morgan, 2003). Radiation-induced genomic instability is characterised by the appearance in cell populations, of progeny with higher than normal levels of non-clonal cytogenetic abnormalities and cell death. The instability is persistent but effects occur at a stable rate in the post irradiation survivors for many generations. Affected progeny populations do not either die out or dominate - an apparent paradox, which is difficult to reconcile with current the "world view" of competitive natural selection of favourable genes. The mechanism of perpetuation is now thought to be epigenetic and to involve an excess generation of reactive oxygen species (ROS) which results in a vicious circle by which stressed cells in turn send out signals and continue the oxidative stress. This is "signaled" to neighbours and perpetuated in progeny via mechanisms similar to the bystander mechanisms discussed earlier. The transmissible factors are very likely to be related to "bystander factors".

While knowledge about radiation-induced genomic instability and bystander effects has been growing in the radiation field for over 15 years, it has only recently become apparent that chemicals in the natural environment can also induce the state of genomic instability in cells and hence low dose chemical toxicity probably also involves bystander effects (Mothersill et al., 1998; Coen et al., 2001). This 
widens the relevance of these indirect damage mechanisms to include environmental toxins other than radiation and makes it important to understand the mechanisms involved as they may contribute to mixed exposure responses in biota.

\section{Relevance of bystander effects in the adaptive response field}

Evidence which suggests that bystander mechanisms may be involved in adaptive responses comes from published data and also from deductive reasoning. The published data show that signals produced by irradiated cells can induce protection against a real dose of ionizing radiation (Mothersill and Seymour, 2002; Maguire et al., 2005). These authors have also shown that intracellular calcium fluxes precede the induction of responses in bystander cells exposed to signals from irradiated cells (Trosko, 1998; Lyng et al., 2000, 2002a, 2002b). While the response that generally follows exposure to these bystander signals is cell death, this can be protective if it eliminates damaged cells from the population. Following low dose exposure where few cells will have damage, it seems appropriate to remove them. At higher doses where many cells are damaged, and tissue integrity is at risk of collapse, such a bystander effect would be an added problem for an already compromised population. It is interesting to note here, that repair deficient cells have larger death-inducing bystander effects than the corresponding repair proficient parent lines (Nagasawa et al., 2003; Mothersill et al., 2005). This would be expected if the damaged cell cannot be repaired if the bystander effect is assumed to be protective. Many cell lines and most tumour explants do not produce death-inducing signals after exposure to radiation and no calcium pulse is seen (Mothersill et al., 2002, 1996; Nagar et al., 2003). It is not known whether they produce no signals or whether different signals not transduced through the calcium pulse-apoptotic death pathway are involved.

\section{Models and relevance to radiation protection}

If we accept that bystander effects are the result of a generalized stress response in tissues or cells, what are the implications for radiation protection? Does the effect alter the acceptability of the Linear-No-Threshold hypothesis upon which all radiation protection legislation is based? How can dose be used as a measure of effect or harm, if low doses (which are those experienced in the workplace), do not produce any type of linear dose-effect curve. There is clearly some very complex biology involved because the signals may be produced by all exposed cells but the response appears to require a quoram in order to be expressed (Gerashchenko and Howell, 2003; Mothersill and Seymour, 1997b; Erickson and Barcellos-Hoff, 2003; Bishayee et al., 2001). The major response involving low LET radiation exposure discussed in the existing literature is a death response. This has many 


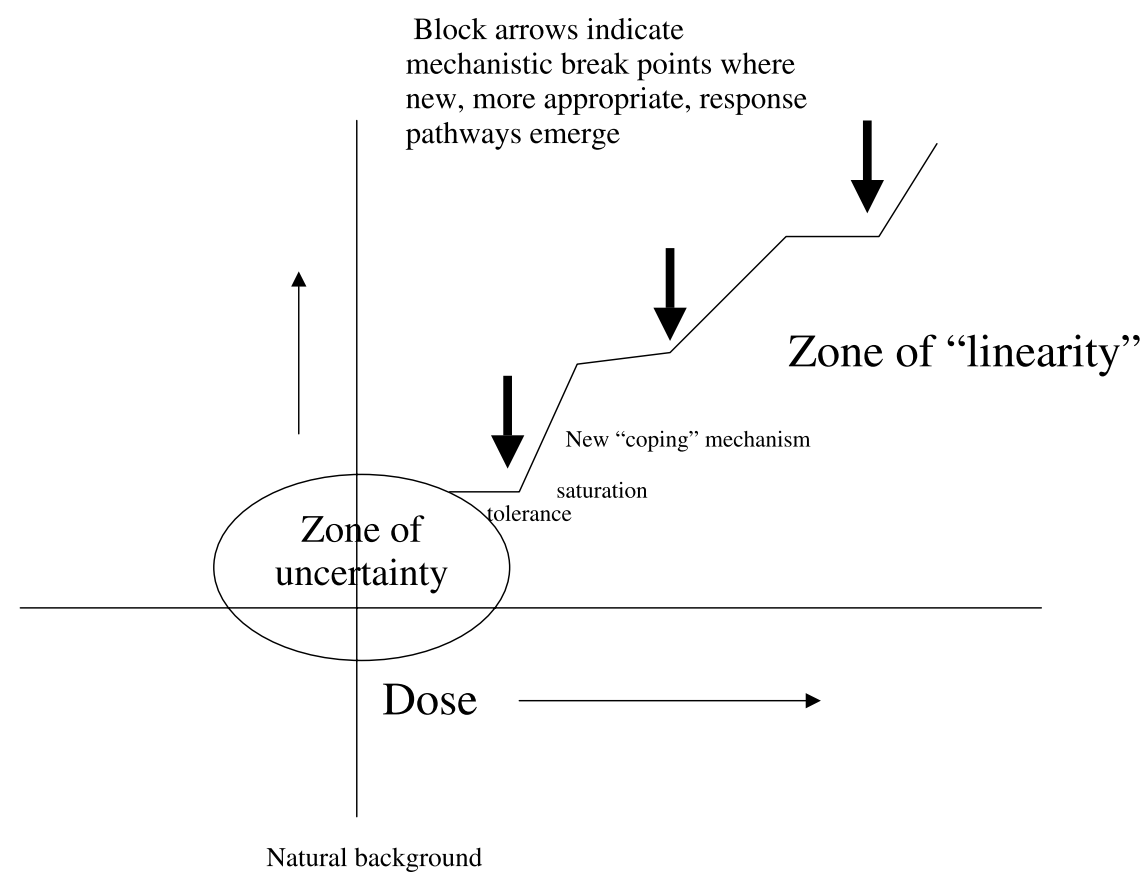

Figure 1 - Proposed dose response relationship for radiation-induced.

Proposition pour une relation dose - réponse cellulaire après exposition aux rayonnements ionisants.

characteristics of apoptosis but is p53 independent. While a death response might appear to be adverse, the position is argued in this paper, that it can be protective and remove damaged cells from the population. Since many cell populations carry damaged cells without being exposed to radiation (so-called "background damage"), it is possible that low doses exposures cause removal of cells damaged by agents other than the test dose of radiation. Alternatively, in genetic backgrounds where the death response is compromised or inactivated, the low dose will cause higher than expected damage and could lead to genomic instability and cancer. This mechanism could lead to the production of "u- or n-shaped" dose response curves so common in toxicology (Calabrese and Baldwin, 2001a, 2001b, 2002). In this scenario, the level of "adaptive" or beneficial response will be related to the level background damage carried by the cell population. A possible way of going forward might be to consider the low dose region as a "zone of uncertainty" (see Fig. 1). In this region, it is not possible to predict accurately, what the outcome of exposure to a dose will be, because of all the factors influencing 
the response. These considerations may be important when attempting to predict the consequences of mixed exposures involving radiation and other environmental stressors.

\section{Conclusion}

To conclude, it is clear that adaptive responses, bystander effects and genomic instability, belong to a suite of effects which predominately modulate the low dose response to radiation. These mechanisms are part of the cellular homeostatic response and while we can detect low dose effects, there is little evidence that these translate into harm. It is likely that for many genotypes there is an operational threshold for harmful radiation damage which probably occurs at a point where the functional activity of the tissue is being compromised by the level of (protective) cell death. For genotypes where the bystander response, if there is one, does not involve coordinated cell death, it is likely that there is no operational threshold and that stochastic effects such as carcinogenesis have some very small probability of occurring at low doses. What this probability is though, is not easy to determine. It is unlikely to be definable by extrapolation from high dose data since the underlying mechanisms are so different. Many of the current research efforts in this field are aimed at modulating the bystander effect using chemicals. This approach should, perhaps, not only look at preventing the bystander effect but also at causing or simulating it in tissues and cells which do not have the capacity to mount this response.

Acknowledgements. We acknowledge support from The Canadian Canada Research Chair program and from the National Science and Engineering Research Council (NSERC).

\section{REFERENCES}

Azzam E.I., De Toledo S.M., Spitz D.R., Little J.B. (2002) Oxidative metabolism modulates signal transduction and micronucleus formation in bystander cells from alpha-particle-irradiated normal human fibroblast cultures, Cancer Res. 62, 5436-5442.

Azzam E.I., De Toledo S.M., Little J.B. (2003) Oxidative metabolism, gap junctions and the ionizing radiation-induced bystander effect, Oncogene 13, 7050-7057.

Balcer-Kubiczek E.K., Harrison G.H., Xu J.F., Gutierrez P.L. (2002) Coordinate late expression of trefoil peptide genes (pS2/TFF1 and ITF/TFF3) in human breast, colon, and gastric tumor cells exposed to X-rays, Mol. Cancer Ther. 6, 405-415.

Barcellos-Hoff M.H., Brooks A.L. (2001) Extracellular signaling through the microenvironment: a hypothesis relating carcinogenesis, bystander effects, and genomic instability, Radiat. Res. 156, 618-627.

Baverstock K. (2000) Radiation-induced genomic instability: a paradigm-breaking phenomenon and its relevance to environmentally induced cancer, Mutat. Res. 254, 89-109. 
Belyakov O.V., Folkard M., Mothersill C., Prise K.M., Michael B.D. (2002) Bystander-induced apoptosis and premature differentiation in primary urothelial explants after charged particle microbeam irradiation, Radiat. Prot. Dosim. 99, 249-251.

Belyakov O.V., Folkard M., Mothersill C., Prise K.M., Michael B.D. (2003) A proliferation-dependent bystander effect in primary porcine and human urothelial explants in response to targeted irradiation, Br. J. Cancer. 88, 767-774.

Bishayee A., Hill H.Z., Stein D., Rao D.V., Howell R.W. (2001) Free radical-initiated and gap junctionmediated bystander effect due to nonuniform distribution of incorporated radioactivity in a three-dimensional tissue culture model, Radiat. Res. 155, 335-44.

Burlakova E.B., Mikhailov V.F., Azurik V.K. (2001) The redox homeostasis system in radiationinduced genomic instability, Radiat. Biol. Radioecol. 41, 489-499.

Calabrese E.J., Baldwin L.A. (2001a) The frequency of U-shaped dose responses in the toxicological literature, Toxicol. Sci. 62, 330-338.

Calabrese E.J., Baldwin L.A. (2001b) Hormesis: U-shaped dose responses and their centrality in toxicology, Trends Pharmacol. Sci. 22, 285-291.

Calabrese E.J., Baldwin L.A. (2002) Applications of hormesis in toxicology, risk assessment and chemotherapeutics, Trends Pharmacol. Sci. 23, 331-337.

Coates P.J., Lorimore S.A., Lindsay K.J., Wright E.G. (2003) Tissue-specific p53 responses to ionizing radiation and their genetic modification: the key to tissue-specific tumour susceptibility?, $J$. Pathol. 201, 377-388.

Coen N., Mothersill C., Kadhim M., Wright E.G. (2001) Heavy metals of relevance to human health induce genomic instability, J. Pathol. 195, 293-299.

Davies M.J. (2003) Singlet oxygen-mediated damage to proteins and its consequences, Biochem. Biophys. Res. Commun. 305, 61-70.

Dent P., Yacoub A., Fisher P.B., Hagan M.P., Grant S. (2003) MAPK pathways in radiation responses, Oncogene. 22, 5885-5896.

Emerit I., Oganesian N., Arutyunian R., Pogossian A., Sarkisian T., Cernjavski L., Levy A., Feingold J. (1997) Oxidative stress-related clastogenic factors in plasma from Chernobyl liquidators: protective effects of antioxidant plant phenols, vitamins and oligoelements, Mutat. Res. 377, 239-246.

Erickson A.C., Barcellos-Hoff M.H. (2003) The not-so innocent bystander: the microenvironment as a therapeutic target in cancer, Expert. Opin. Ther. Targ. 7, 71-88

Faguet G.B., Reichard S.M., Welter D.A. (1984) Radiation-induced clastogenic plasma factors, Cancer Genet. Cytogenet. 12, 73-83.

Geard C.R., Jenkins-Baker G., Marino S.A., Ponnaiya.B. (2002) Novel approaches with track segment alpha particles and cell co-cultures in studies of bystander effects, Radiat. Prot. Dosim. 99, 233236.

Gerashchenko B.I., Howell R.W. (2003) Cell proximity is a prerequisite for the proliferative response of bystander cells co-cultured with cells irradiated with gamma-rays, Cytometry 56A, 71-80.

Iyer R., Lehnert B.E. (2002a) Low dose, low-LET ionizing radiation-induced radioadaptation and associated early responses in unirradiated cells, Mutat. Res. 503, 1-9.

Iyer R., Lehnert B.E. (2002b) Alpha-particle-induced increases in the radioresistance of normal human bystander cells, Radiat. Res. 157, 3-7.

Keyes E., Howe O., Seymour C.B., Lyng F., Mothersill C. (2005) Prolonged expression of delayed cell death in the progeny of cells exposed to direct irradiation or to culture medium from irradiated cells, Int. J. Radiat. Biol. (being revised).

Lehnert B.E., Iyer R. (2002) Exposure to low-level chemicals and ionizing radiation: reactive oxygen species and cellular pathways, Hum. Exp. Toxicol. 21, 65-69. 
Limoli C.L., Giedzinski E. (2003) Induction of chromosomal instability by chronic oxidative stress, Neoplasia. 5, 339-346.

Little J.B., Morgan W.F. (Eds.) (2003) Oncogene 13, 69-77.

Little J.B., Azzam E.I., De Toledo S.M., Nagasawa H. (2002) Bystander effects: intercellular transmission of radiation damage signals, Radiat. Prot. Dosim. 99, 159-162.

Lorimore S.A, Wright E.G. (2003) Radiation-induced genomic instability and bystander effects: related inflammatory-type responses to radiation-induced stress and injury? A review, Int. J. Radiat. Biol. 79, 15-25.

Lorimore S.A., Coates P.J., Scobie G.E., Milne G., Wright E.G. (2001) Inflammatory-type responses after exposure to ionizing radiation in vivo: a mechanism for radiation-induced bystander effects?, Oncogene 20, 7085-7095.

Lorimore S.A., Coates P.J., Wright E.G. (2003) Radiation-induced genomic instability and bystander effects: inter-related nontargeted effects of exposure to ionizing radiation, Oncogene 22, 70587069

Lyng F.M., Seymour C.B., Mothersill C. (2000) Production of a signal by irradiated cells which leads to a response in unirradiated cells characteristic of initiation of apoptosis, Br. J. Cancer. $\mathbf{8 3}$, 1223-1230.

Lyng F.M., Seymour C.B., Mothersill C. (2002a) Early events in the apoptotic cascade initiated in cells treated with medium from the progeny of irradiated cells, Radiat. Prot. Dosim. 99, 169-172.

Lyng F.M., Seymour C.B., Mothersill C. (2002b) Initiation of apoptosis in cells exposed to medium from the progeny of irradiated cells: a possible mechanism for bystander-induced genomic instability?, Radiat. Res. 157, 365-370.

Maguire M., Mothersill C., Seymour C.B., Lyng F.M. (2005) An adaptive response following exposure of cultures to medium from cells irradiated to low doses of cobalt 60 gamma rays, Radiat. Res. (in preparation).

Morgan W.F. (2003) Non-targeted and delayed effects of exposure to ionizing radiation: I. Radiationinduced genomic instability and bystander effects in vitro, Rad. Res. 159, 567-580.

Mothersill C., Seymour C. (1997a) Medium from irradiated human epithelial cells but not human fibroblasts reduces the clonogenic survival of unirradiated cells, Int. J. Radiat. Biol. 71, 21-7.

Mothersill C., Seymour C. (1997b) Survival of human epithelial cells irradiated with cobalt 60 as microcolonies or single cells, Int. J. Radiat. Biol. 72, 597-606.

Mothersill C., Seymour C.B. (1998) Cell-cell contact during gamma irradiation is not required to induce a bystander effect in normal human keratinocytes: evidence for release during irradiation of a signal controlling survival into the medium, Radiat. Res. 149, 256-262.

Mothersill C., Seymour C.B. (2002) Bystander and delayed effects after fractionated radiation exposure, Radiat. Res. 158, 626-633.

Mothersill C., Seymour C. (2003) Low-dose radiation effects: experimental hematology and the changing paradigm, J. Exp. Haematol. 31, 437-445.

Mothersill C., Lyng F., O'reilly S., Harney J., Seymour C.B. (1996) Expression of lethal mutations is suppressed in neoplastically transformed cells and after treatment of normal cells with carcinogens, Radiat. Res. 145, 714-721.

Mothersill C., Crean M., Lyons M., Mcsweeney J., Mooney R., O'reilly J., Seymour C.B. (1998) Expression of delayed toxicity and lethal mutations in the progeny of human cells surviving exposure to radiation and other environmental mutagens, Int. J. Radiat. Biol. 74, 673-680.

Mothersill C., Stamato T.D., Perez M.L., Cummins R., Mooney R., Seymour C.B. (2000) Involvement of energy metabolism in the production of 'bystander effects' by radiation, Br. J. Cancer. 82, 1740-1746. 
Mothersill C., Rea D., Wright E.G., Lorimore S.A., Murphy D., Seymour C.B., O'malley K. (2001) Individual variation in the production of a 'bystander signal' following irradiation of primary cultures of normal human urothelium, Carcinogenesis 22, 1465-1471.

Mothersill C., Seymour C.B., Joiner M.C. (2002) Relationship between radiation-induced low-dose hypersensitivity and the bystander effect, Radiat. Res. 157, 526-532.

Mothersill C., Seymour R.J., Seymour C.B. (2005) Bystander effects in repair deficient cell lines, Radiat. Res. (accepted).

Nagar S., Smith L.E., Morgan W.F. (2003) Characterization of a novel epigenetic effect of ionizing radiation: the death-inducing effect, Cancer. Res. 63, 324-328.

Nagasawa H., Little J.B. (1992) Induction of sister chromatid exchanges by extremely low doses of alpha-particles, Cancer Res. 52, 6394-6396.

Nagasawa H., Huo L., Little J.B. (2003) Increased bystander mutagenic effect in DNA double-strand break repair-deficient mammalian cells, Int. J. Radiat. Biol. 79, 35-41.

Osterreicher J., Prise K.M., Michael B.D., Vogt J., Butz T., Tanner J.M. (2003) Radiation-induced bystander effects. Mechanisms, biological implications, and current investigations at the Leipzig LIPSION facility, Strahlenther Onkol. 179, 69-77.

Prise K.M., Belyakov O.V., Folkard M., Michael B.D. (1998) Studies of bystander effects in human fibroblasts using a charged particle microbeam, Int. J. Radiat. Biol. 74, 793-798.

Prise K.M., Belyakov O.V., Newman H.C., Patel S., Schettino G., Folkard M., Michael B.D. (2002) Non-targeted effects of radiation: bystander responses in cell and tissue models, Radiat. Prot. Dosim. 99, 223-226.

Prise K.M., Folkard M., Michael B.D. (2003) A review of the bystander effect and its implications for low-dose exposure, Radiat. Prot. Dosim. 104, 347-355.

Reznikov K., Kolesnikova L., Pramanik A., Tan-No K., Gileva I., Yakovleva T., Rigler R., Terenius L., Bakalkin G. (2000) Clustering of apoptotic cells via bystander killing by peroxides, FASEB J. 14, 1754-1764.

Sawant S.G., Zheng W., Hopkins K.M., Randers-Pehrson G., Lieberman H.B., Hall E.J. (2002) The radiation-induced bystander effect for clonogenic survival, Radiat. Res. 157, 361-364.

Seymour C.B., Mothersill C. (2000) Relative contribution of bystander and targeted cell killing to the low-dose region of the radiation dose-response curve, Radiat. Res. 153, 508-511.

Seymour C.B., Mothersill C., Mooney R., Moriarty M., Tipton K.F. (2003) Monoamine oxidase inhibitors 1-deprenyl and clorgyline protect nonmalignant human cells from ionising radiation and chemotherapy toxicity, Br. J. Cancer. 89, 1979-1986.

Shao C., Furusawa Y., Kobayashi Y., Funayama T., Wada S. (2003) Bystander effect induced by counted high-LET particles in confluent human fibroblasts: a mechanistic study, FASEB J. 17, 1422-1427.

Trosko J.E. (1998) Hierarchical and cybernetic nature of biologic systems and their relevance to homeostatic adaptation to low-level exposures to oxidative stress-inducing agents, Environ. Health Perspect. 106 (Suppl. 1), 331-339.

Zhou H., Randers-Pehrson G., Suzuki M., Waldren C.A., Hei T.K. (2002) Genotoxic damage in nonirradiated cells: contribution from the bystander effect, Radiat. Prot. Dosim. 99, 227-232.

Zhou H., Randers-Pehrson G., Geard C.R., Brenner D.J., Hall E.J., Hei T.K. (2003) Interaction between radiation-induced adaptive response and bystander mutagenesis in mammalian cells, Radiat. Res. 160, 512-516. 